\title{
Joyce the Deconstructionist: Finnegans Wake in Context
}

\author{
Zangouei, J. \\ Instructor of English, English Department, University of Birjand, Birjand, IRAN \\ e-mail: Javad.Zangouei@Gmail.Com
}

\begin{abstract}
Had Finnegans Wake not been written, some seminal post-1950s innovations in the field of modern literary theory and criticism would have been impossible. James Joyce, who seems to have inspiringly influenced the entire sphere of modern literary theory and criticism greatly, is a pioneer of deconstruction too. His last novel, which reflects his deconstructive tendencies, has played a seminal role in the formation of $20^{\text {th }}$ century deconstruction, and comprises an inchoate mass of implicit ideas on the subject. It was perhaps not until Jacques Derrida and his deconstruction techniques that the theory implied by Finnegans Wake really came into focus. This article seeks to delineate Derrida's theory of deconstruction as well as Joyce's deconstructive aesthetics; and taking a diachronic approach to literary theory and criticism it glances at Finnegans Wake in the light of deconstruction.
\end{abstract}

Key words: Deconstruction, Derrida, différance, Finnegans Wake, Joyce, logocentrism.

"Every time I write, and even in the most academic pieces of work, Joyce's ghost is always coming on board" (Derrida, 1984b, p. 149).

"I [Derrida] have never imitated anyone so irresistibly" [as I've imitated Joyce] (Derrida, 1987, p. 142).

"Deconstruction could not have been possible without Joyce" (as cited in Jones, 1988, p. 77).

\section{INTRODUCTION}

About three decades after the publication of Finnegans Wake, Joyce's last novel, Jacques Derrida presented his seminal lecture "Structure, Sign, and Play in the Discourse of the Human Sciences" at Johns Hopkins University (1966) and so inaugurated his theory of deconstruction. As to the formation of deconstruction, Derrida himself said that he had been under Joyce's influence: Finnegans Wake has had an undeniably significant role in the formation of Derrida's theory. This article proceeds to deal with deconstruction's tenets as well as Joyce's deconstructive aesthetics, and glance Finnegans Wake in the light of deconstruction.

Deconstruction, which originates in the writings of the French philosopher Jacques Derrida, targets centripetal forces, zeroes in on Western tradition seeking to undermine it through undoing its hierarchical oppositions, scrutinizes authority in language, and speculates the final dissolution of foundational thought. Its originator, Derrida, as the first theorist of $20^{\text {th }}$ century deconstruction, celebrates the way his critical thinking has been shaped by Joyce's oeuvre, especially Finnegans Wake; In "Two Words for Joyce", Derrida compares Finnegans Wake to a "1000th generation computer" and explicitly admits that he has been strongly affected by Joyce: "Every time I write, and even in the most academic pieces of work, Joyce's ghost is always coming on board" (Derrida, 1984b, pp. 147-49); Moreover, in The Post Card (1987), referring to Joyce's influence on the formation of his theories, he goes further confessing that he has 'never imitated anyone so irresistibly' as he has imitated Joyce; And interestingly, Derrida formally remarks in the 1984 Joyce symposium that 'without Joyce', 'Deconstruction could not have been possible.' Joyce's work, then, occupies a central place in deconstruction which in its turn has drastically influenced contemporary literary theory and criticism.

Joyce is a pioneer of deconstruction Finnegans Wake being its "sperm seed" (Wang, 1992, p. 77). In this novel, which is his last writing practice, Joyce completes the revolution both in form (structure) and content of the novel. Finnegans Wake, as Joyce's "smithy of soul", reflects him forging not only "the uncreated conscience of [his own] race (Joyce, 1969 , p. 253) but also the uncreated conscience of the World race. With regard to both content and form of the novel as well as Derrida's sayings concerning Joycean influence and inspiration, Finnegans Wake can be viewed as a unique yardstick for Derridean deconstruction. Derrida's aforementioned confessions about Joyce's influences, especially that of Finnegans Wake (Knowlton, 1998, p. 113), on the formation of his theory and Jennie Wang's idea on the seminal influence of Finnegans Wake on deconstruction would legitimize writing this essay on the relationship between as well as the analogy of Joycean and Derridean deconstructions. So, the essay proceeds to delineate both Derridean deconstruction and Joycean deconstruction respectively. 


\section{DERRIDEAN DECONSTRUCTION: AN INTRODUCTION}

Taking the whole history of western philosophy into account, Derrida considers it as one continuous attempt aimed at locating a fixed permanent center which since Plato has always been thought of in terms of presence. He argues that "it could be shown that all the names related to fundamentals, to principles, or to the center have always designated an inevitable presence-eidos, arche, telos, energeia, ousia, (essence, existence, substance, subject), aletheia, transcendentality, consciousness, God, man, and so forth which he names as the metaphysics of presence and believes that it has been present in western philosophy in the form of privileging voice over writing (Derrida, 1978, pp. 279-81): Voice has always been regarded as the medium of meaning and writing as derivative and inessential.

Privileged over writing, voice became "a metaphor of truth and authenticity, a source of self-present 'living speech' as opposed to the secondary lifeless emanations of writing" (Norris, 1996, p. 28). Consequently, signifiers such as presence, goodness, truth, and wisdom were attached to voice or speech; And the opposites of the same signifies such as absence, badness, falsity, and foolishness were imposed on writing.

Furthermore, in Western tradition, as Derrida believes, there is a metaphysical system which strangely assigns the origin of truth to speech or Logos (Derrida, 1976, p. 3) which he names logocentrism whose deconstruction occupies a central place in his writings. What Derrida attempts to show is that the presence of speech (as origin) cannot be articulated without the help of that which is thought of as secondary to it, without the help of what is absent; namely, of writing. Then, presence cannot present itself, but needs the help of what is not present, of absence, of writing.

Furthermore, from a deconstructive viewpoint, meaning is created only by differences and sustained by reference to, or affirmation of other meanings (difference and deferral). Since meaning, as Derrida says, has been depended upon the existence of an unsignified or transcendental signified, its nature is logocentric. In the Western tradition the relation between the signifier and the signified is understood in terms of representation, i.e., the signifier represents the signified, or, better to say, the signifier represents the presence of the signified which implies that the presence of the signified is the origin of the meaning of the signifier. However, in order to serve as origin, the signified itself must be unsignified and unrepresented; it must be what Derrida names as "transcendental signified" (p. 49). In addition, he critiques this and challenges "the quest for a rightful beginning, an absolute point of departure" (Derrida, 1982, p. 6), a challenge which is present in difference.

\section{Différance}

Derrida coins différance, his "neographism" (p. 13), on the basis of a pun that the French language makes possible meaning difference and deferral simultaneously. He spells his new term with an "a" instead of an "e". The misspelling is noticeable only when the word is written: saying difference and différance makes no difference in French, for, it is pronounced the same way with or without the alteration. By adroitly coining the neographism différance that takes on two simultaneous meanings Derrida seeks ambiguity: in speech one cannot distinguish the difference between the French word difference and differrance, which is Derrida's coinage.

What is unique in Derrida is that differance itself is deconstructed and prevented from becoming a center. As he argues, it "does not mean that the différance that produces differences is before them or superior to them. Différance is the non-full, non-simple, structured and differentiating origin of differences. Thus, the name origin no longer suits" (p. 12), for, différance suggests multiplicity, heterogeneity, plurality, rather than binary opposition and exclusion. Under deconstructive condition, "the absence of the transcendental signified extends the domain and the play of signification infinitely" (Derrida, 1978, p. 280), so that, différance presupposes no kingdom, but "instigates the subversion of any kingdom" (Derrida, 1982, p. 179): différance frustrates interpretation so that there is no ground for attributing a decidable meaning to any utterance that we speak or write. Hence, the ceaseless play of signifiers (and also of signifieds now turned into signifiers); signifiers can never have settled signifieds.

Note well that although to Derrida "language is first ... writing" (Derrida, 1976, p. 37), deconstruction should not be understood as a plea for the inversion of the opposition between speech and writing, for, such an inversion would only replace one origin for another, but would leave the metaphysical order itself in its place. Rather than being destructive, negative, or "an enclosure in nothingness", deconstruction is "openness towards the other" (Derrida, 1984a, p. 124): writing is also a source of meaning. In short, deconstruction approves of the pluralistic coexistence of signifieds.

\section{JOYCES DECONSTRUCTIVE AESTHETICS}

Derrida, as aforementioned, declares that without Joyce there would have been no deconstruction. Though he says that his critical writings has been shaped by Finnegans Wake (as cited in Knowlton, 1998, p. 113), Joyce's deconstructive tendencies and his concern for the other is understood from the beginning of his career; for example in his essay on Clarence Mangan where he says, "certainly, he is wiser who accuses no man of acting unjustly towards him, seeing that what is called injustice is never so, but is an aspect of justice" (Joyce, 1959, p. 76). In the same essay he mentions that "Mangan can tell us of the beauty of hate; and pure hate is as excellent as pure love" (p. 83). Joyce decenters the traditional views of justice and love; he privileges the hitherto unprivileged and shows his openness towards the other. Also, Joyce's concern for the other is manifest in Stephen Dedalus' (Joyce's alter ego) remark on Bruno, the Italian philosopher: "he (Stephen's friend) said Bruno was a terrible heretic. I (Stephen) said he was terribly burned" (Joyce, 1969, p. 249). Joyce's philosophy of art and life retains in itself those characteristics and qualities which 
allow us to consider him as a deconstructionist. Similar to a deconstructionist, Joyce exhibits his concern for the other or margins.

Certainly, Joyce is not orthodox in his religious beliefs and this manifests itself in his judgments about religion. Once, Frank Budgen, Joyce's intimate friend, asks him why he had brought up his children without religious training; Joyce answers "but what do they [Joyce's children] expect me to do? ... There are a hundred and twenty religions in the world. They can take their choice. I should never try to hinder or dissuade them (as cited in Benstock, 1965, p. 102). Joyce is a real pluralist whose viewpoints concerning principles (of religion, of literature, etc.) is centrifugal not centripetal.

Joyce developed a great, pluralistic mind. Innately, he was a greedy reader, reading so widely that "it is hard to say definitely of any important creative work published in the late nineteenth century that Joyce had not read" (Ellmann, 1959, p. 78). Being well familiar with Ibsen and de Saussure (Lernout, 2002, p. 351) who famously interrogated authority in its variant forms, Joyce ironically problematizes their authority: the authority of the former in one of his striking letters and of the latter, in his writing practice. The letter addressed to Ibsen reflects Joyce's antielitism, anti-traditionalism, and iconoclasm. Joyce, as one member of the young generation for whom Ibsen has spoken, in his letter treats him "more as an equal than as a master" admiring Ibsen's "lofty impersonal style, his willful resolution to wrest the secret from life" and more importantly, Ibsen's "absolute indifference to the public canons of art, friends and shibboleth" (Levin, 1960, pp. 32-33). Joyce was completely familiar with and at the same time indifferent to the literary canon.

To Joyce, everything (including truth, etc.), is recurrently constructed and nothing exists substantially but is in a state of flux. The uncertainty that the reader of Finnegans Wake experiences mirrors its author's uncertainties about the world. By writing his novel in a unique and at the same time strange language that encourages uncertainty and plurality, Joyce banishes certainty and monism from its world. Similar to Derrida coming after him, Joyce, in the structure of his last novel, questions Saussurian linguistics. Though différance is directly related to a Structuralist conception of meaning (Derrida, 1976, p. 39), in one crucial aspect it is beyond structuralism: Derrida explicitly denies the original character of structure itself saying that structure is "not a transcendental signified." In this manner, Derrida says that he does not want to question the truth of what Saussure says "On the level on which he says it" but does want to question the logocentric way in which Saussure says it (Derrida, 1976, p. 39, original emphasis). Derrida coins différance to articulate "the differential character of the origin of structure itself (Derrida, 1991, p. 272), and so does Joyce composing his last novel in circular structure.

\section{FINNEGANS WAKE AS DIFFÉRANCE}

Différance implies any language play that postpones meaning; And similar to Derrida, Joyce has faith in writing and in himself as an agent of writing. Since both structure and title of Joyce's last novel defer meaning, they can be taken as unique examples of différance.

Drawing upon the circular structure in his novel, Joyce questions 'the quest for both a rightful beginning, and an absolute point of departure,' as Derrida after him does. Having "[d]oublends" [two ends] (Joyce, 1942, p. 20), Finnegans Wake allows its readers start reading it from whatever page they desire. Also, the novel shows Joyce busy experiencing radical linguistic experimentation: Finnegans Wake, whose language is "a sort of allegory of resistance to linguistic imperialism" (as cited in Booker, 1991, p. 200), reflects the inherent power of written words. The novel utilizes that kind of language which creates an alternative reality: the lingual process, instead of construction, is one of reconstruction. In this way Joyce transforms each word into a "miniature image" creating multiple units capable of "sounding a number of themes simultaneously" (Litz, 1961, p. 59).

Différance implies an always-at-least-double meaning sustained by the tension between the signified object and the very process of signification. The title of the novel, Finnegans Wake, serves as a good example of différance having at-least-double simultaneous referents: In the title, 'Finnegans' simultaneously refers to Tim Finnegan, Bygmester Finnegan, and Finn MacCool. Secondly, the connotations of 'Wake' in the title are 'to be awake,' 'resurrection,' 'night-wake,' and 'funeral-watch.' Thirdly, the missing apostrophe in the title encourages further slippage in signification. In a true Deconstructive fashion, each word in the title implies an at-least-double meaning indicating plurality and diversity.

Furthermore, in terms of content the title of the novel can be considered as différance: in the title, Finn MacCool has more divine connotations than secular ones while Tim Finnegan and Bygmester Finnegan have more secular connotations than divine ones. This reveals another aspect of Joyce's art: in the title of his last novel he combines the divine and secular. In this respect 'Finnegans Wake' as Joycean différance would assume an additional aspect (content aspect) and would go beyond its Derridean counterpart.

Moving on from the title to the text, one witnesses H.C.E. who also signifies and is mourned as Finnegans and their manifestations, Finn McCool, Tim Finnegan, Bygmester Finnegan, etc. H.C.E. or "Mr Whicker" (Joyce, 1942, p. 434), in whom Finnegans are combined, appears under various guises in the novel such as "hod, cement and edifices" (p. 4); "Hush! Caution! Echoland!" (p. 13); "Humme the Cheapner, Esc" (p. 19); "How charmingly exquisite!" (p. 13); "Hag Chivychas Eve" (p. 30); "Here Comes Everybody" (p. 32); "H. C. E." (p. 32); H. C. Earwicker (p. 33); "House, son of Clod . . to be Executed" (p. 70); "Helmingham Erchenwyne Crumwll" (p. 88); "Homo Capite Erectus" (p. 101); "Huffy Chops Eads Excellent" (p. 106); "Hear! Calls! Everywhair!" (p. 108); "East Conna Hillock" (p. 160); "Her Chuff Exsquire!" (p. 205) (as cited in Boldereff, 1959). 
Uniquely, Joyce decenters H.C.E.: any attempt aimed at identifying him as the center of the novel fails. H.C.E. eludes identification: as he appears in a new context, his appearance means a new thing. It is "only after naming a thing that we control it" (Tindall, 1950, p. 99) and Joyce does not name as traditionalist fictionists do.

In literature, deconstruction begins at the moment the author cannot control his text; hence, slippage in signification. Finnegans Wake is an autonomous entity cut loose from the intentionality of its author, programmed in a way as to generate multiple, unpredictable meanings. Of numerous potent examples one can consider the following words as examples of différance: "collideorescape" (Joyce, 1942, p. 143) simultaneously signifies collide or escape -- in the novel signifiers collide with and escape from each other; "reignbeau" (p. 203) connotes 'rainbow', and 'the reign of bow'; "sinse" in the phrase "pleasekindly communicake with the original sinse we are only yearning" (p. 239), simultaneously signifies 'since' and 'sins'; "a rhythmatick" (p. 268) simultaneously suggests 'unrythmatic' and 'arithmetic'; "The beautfour sisters" (p. 393), simultaneously connotes 'four beautiful sisters', 'but for sisters,' and 'but four sisters'; "Lust" (p. 433) in Shaun's sermon connotes 'lust' and 'last'; "kommen" (p. 437) signifies come on, come in, and come men "Beleave filmly, beleave" (p. 610) signifies 'to be leaving' and 'to believe in.' Having no center to establish a settled structure in it, Finnegans Wake blocks any movement towards determinate meaning and cannot be read referentially.

\section{The Deconstructed World of Finnegans Wake}

Finnegans Wake presents deconstructed world where words and phrases simultaneously signify in several different directions; in this novel the reader and the text affect each other and Joycean deconstruction becomes a kind of "hermeneutics free--for--all" (Norris, 1987, p. 139), a joyous release from all the rules and constraints of interpretation and understanding.

Finnegans Wake reflects a world where nothing is literal. In this novel every expression simultaneously belongs to several frames of reference none of them identifiable as the basic one. While reading Finnegans Wake, its reader has to abandon two assumptions about the reading process (Attridge, 1990, p. 11):

1. That reading is an act of mastery.

2. That reading is a passive experience.

In, Finnegans Wake, his "new Irish stew" (Joyce, 1942, p. 190), Joyce exploits all the potentialities of language; constantly using portmanteau words, he is "seldom content with only two meanings" (Litz, 1966, p. 104). Being an endless play and deferral of meaning, Finnegans Wake reflects an indefinable process of becoming in language that continually defeats any attempt aimed at analysis and definition. The composition of Finnegans Wake where Joyce revives the Swiftian tradition of "the pen is mightier than the sword" marks a fundamental change in the style of writing and is historically significant (Wang, 1992, p. 77). Joyce emphasizes writing, reveals its controlling power and finally demarginalizes writing.
Joyce in his last novel creates new linguistic codes. Once asked "Aren't there enough words for you in five hundred thousand [words] of the English language?" Joyce answered, "Yes, there are enough of them, but they are not the right ones" (Budgen, 1963, p. 19). Using words like musical chords, he says several things at once in a single expression: Joyce coins kaleidoscopic words with as infinite series of meanings none of them subordinated to any other. To take an example of such words, the word "papacocopotl" (Litz, 1961, p. 73; Joyce, 1942, p. 294) consists of four major components. They are:

1. Papa: Joyce's hero, H.C.E. who is all fathers

2. Popocateptel: H.C.E. is identified with all mountains.

3. Coco: cocoa in Finnegans Wake is the body of god, suggesting HCE in his sacramental role.

4. Pot: A vulgar reminder of H.C.E.'s indiscretion in Phoenix Park.

Joyce loads Finnegans Wake's diction with simultaneous effects so that it offers great resistance to reader's efforts to comprehend it. The interrogation of the fundamental concepts on which meaning relies is an ongoing concern in Derrida's work and Joyce's novel.

Consequently, as Derrida also suggests, we cannot speak of reading Joyce since it is "not merely naive, but mistaken" (Conley, 2003, p. 11). Finnegans Wake is a text "where terms begin" (Joyce, 1942, p. 452), and so, we "shall be misunderstood if understood" (p. 163) and you are reminded that you are reading a text "above [your] understanding" (p. 152).

Joyce, like Derrida, is "fond of that other of [his]" (p. 408) and privileges no idea over the other. He makes Finnegans Wake rewrite "its wrunes[alphabetical system; words] for ever" (p. 19): its diction, "differently pronounced, otherwise spelled" (p. 118), mean several meanings at once. Deconstruction helps readers understand that any text slips the boundaries laid upon it. Joyce in his last novel makes the best use of ambiguity, and therefore, he constructs a world that is as uncertain as possible. Joyce's novel is rich in figurative devices and exploits the phonological level of language extensively.

\section{CONCLUSION}

Joyce's thought resists any philosophy or world view which offers an absolutist version of Truth. In Finnegans Wake, which can be viewed an early treatise on deconstruction, he treats the Western tradition skeptically. Joyce's privileging of 'writing' over 'speech' actually reverses the more usual (to Western Tradition) prioritizing of 'speech' over 'writing.' His meditation on the primacy of 'writing' over 'speech' foreshadows Derridean deconstruction which resists centrism and seeks to deconstruct the Western tradition.

Logocentrism, which as the basic idea behind metaphysics of presence nurtures the illusion of arriving at a final meaning, is Derrida's target. Similarly, Finnegans Wake is an anti-logocentric novel where Joyce allows the unrepresentable (unsignified) or transcendental signified, "to become perceptible in his writing itself, in the signifier" 
(Lyotard, 2001, p. 61), and does not provide his reader with a definitive, logocentric text with decidable meanings: Joyce's presentation of the unsignified and the unrepresentable deprives Finnegans Wake's world of a 'transcendental signified.' In Joyce's last novel center is changed into "function, into a sort of nonlocus in which an infinite number of sign-substitutes come into play" (Derrida, 1978, p. 280). Joyce, in whose hand English is dough, manipulates the language to a degree unmatched in this century.

A call of liberation from the hegemony of certainty resonates throughout Finnegans Wake which concerns itself with the interaction of reader and text. The tension in its language bars semantic certainty so that the lack of determinate signifieds creates ontological instability. By emphasizing différance Joyce challenges the reader to become actively involved in the laudable text and engage in experiencing its bliss rather than its pleasure. In this regard, the supposedly opaque, or nonsensical, language of the novel opens up as a rich source for the reader's reflections: though readers won't all approach it the same way, or with the same set of references, there is meaning in it for everyone. Note bene that although in Finnegans Wake writing is privileged over speech and Joyce employs the technique of substitution instead of repetition, he ironically shows language's inadequacy in identifying people and their situation. He seems to be cautious not to reverse the binaries and establish another center.

\section{REFERENCES}

Attridge, D. (1990). Reading Joyce. In D. Attridge (Ed.), The Cambridge companion to James Joyce (pp. 1-27). Cambridge: Cambridge University Press.

Benstock, B. (1965). Joyce-again's wake: An analysis of Finnegans Wake. Seattle and London: University of Washington Press.

Boldereff, F.M. (1959). Reading finnegans wake. Woodward, PA: Classic Nonfiction Library.

Booker, M. K. (1991). Finnegans wake and the satanic verses: Two modern myths of the fall. Critique: Studies in Contemporary Fiction, 32, 190-207.

Budgen, F. (1963). James Joyce. In E. Jolas \& S. Manley (Eds), James Joyce: Two decades of criticism (pp.1927). Givens, New York: The Vanguard Press.

Conley, T. (2003) Performance anxieties: On failing to read finnegans wake. Papers On Language and Literature, 39, 71-90.

Derrida, J. (1976). Of grammatology (G.C. Spivak, Trans.). Baltimore and London: The John Hopkins University Press. (Original work published 1967)

Derrida, J. (1978). Writing and difference (A. Bass, Trans.). Chicago: The University of Chicago Press. (Original work published 1967).
Derrida, J. (1982). Margins of philosophy (A. Bass, Trans.). Chicago: The University of Chicago Press.

Derrida, J. (1984a). Dialogue with Jacques Derrida: Deconstruction and the other. In R. Kearney (Ed.), Dialogue with contemporary continental thinkers: The phenomenological heritage (pp. 105-126). Manchester: Manchester University Press.

Derrida, J. (1984b). Two words for Joyce. (G. Bennington, Trans.). In D. Attridge \& D. Ferrer (Eds.), Poststructuralist Joyce: Essays from the French (pp. 14559). Cambridge: Cambridge University Press.

Derrida, J. (1987). The post card: From Socrates to Freud and beyond (Alan Bass, Trans.). Chicago: University of Chicago Press. (Original work published 1980)

Derrida, J. (1991). Letter to a Japanese friend (D. Wood \& A. Benjamin, Trans.). In P. Kamuf (Ed.), Derrida reader: Between the blinds (pp. 270-6). New York: Columbia University Press.

Ellmann, R. (1959). James Joyce. New York: Oxford University Press.

Jones, E. C. (1988). Deconstructive criticism of Joyce: Introduction. In B. Benstock (Ed.), James Joyce: The augmented ninth (pp. 77-79). Syracuse: Syracuse University Press.

Joyce, J. (1942). Finnegans wake. London: Faber and Faber.

Joyce, J. (1959). James Clarence Mangan. In E. Mason \& R. Ellmann (Eds.), The critical writings of James Joyce (pp. 73-83). London: Faber and Faber.

Joyce, J. (1969). A portrait of the artist as a young man, London: Penguin.

Knowlton, E. (1998). Joyce, Joyceans, and the rhetoric of citation. Gainesville: Florida University Press.

Lernout, G. (2002). Crises in Joyce studies. Studies in the Novel, 34, 337-351.

Levin, H. (1960). James Joyce: A critical introduction. London: Faber and Faber.

Litz, A.W. (1961). The art of James Joyce: Method and design in Ulysses and Finnegans Wake. New York: Oxford University Press.

Litz, A.W. (1966). James Joyce. New York: Twayne Publishers, Inc.

Lyotard, J.F. (2001). Answering the question: What is postmodernism? In S. Malpas (Ed.), Postmodern debates (pp. 53-61). New York: Palgrave.

Norris, C. (1987). Derrida. Cambridge, MA: Harvard University Press.

Norris, C. (1996). Deconstruction: Theory and practice. London and New York: Routledge.

Tindall, W.Y. (1950). James Joyce, his way of interpreting the modern world. New York: Scribner.

Wang, J. (1992). To wielderfight his penisolate war: The lover's discourse in postmodernist fiction. Critique: Studies in Contemporary Fiction, 34, 63-79. 